\title{
The Tenure Security and Its Implication to Self-Help Housing Improvements in the Urban Kampong: The Case of Kampong Cikini, Jakarta
}

\author{
Joko Adianto $^{*}$, Akiko Okabe ${ }^{* *}$, Evawani Ellisa ${ }^{* * *}$, Norihisa Shima ${ }^{* * *}$
}

\begin{abstract}
Jakarta has been experiencing rapid urbanization and severe housing shortage, especially for the under privileged. This condition breeds slum, or kampong in Indonesia, as solution to provide affordable housing. In the absence of right of ownership, as the basis of objective secure tenure, kampong dwellers have been delivering self-help house improvements. It proves subjective tenure security, as alternative of objective tenure security, encourages self-help housing. The research aims are identifying the general condition of landownership, the other factors of subjective tenure security that become impediment of land titling program and its implication to house condition in Kampong Cikini, Jakarta, as the research area. The information was obtained from 79 respondents by utilizing snowball technique sampling. The findings indicated only small numbers of respondents obtained right of ownership, while most of respondents claimed landownership based on documents that referred to colonial, customary and religion laws. It described inadequate knowledge of the land regulation of kampong dwellers, following by expensive and complicated procedure, as the impediment of land titling program. Escalating land price, kampong improvements programs and support from political parties become other factors that strengthen subjective tenure security which encourage self-help house improvements. This research is not only complemented the existing theory of subjective tenure security but also demonstrated how the intricate tenure security and its implication to self-help housing improvements in kampong settlement. It will useful on refining the the new implemented intervention to improve kampong without degrading formal land titling program.
\end{abstract}

\section{Keywords:}

Tenure security, land registration, housing improvement, Urban kampong, Jakarta

\footnotetext{
${ }^{*}$ Assistant Professor at Universitas Indonesia, ${ }^{* *}$ Professor at University of Tokyo, Japan, ${ }^{* * *}$ Associate Professor at Universitas Indonesia, Associate Professor at Toyo University, Japan.

Email: joko.adianto@gmail.com
} 


\section{BACKGROUND}

\subsection{Slum Settlement and the Case of Jakarta}

The rapid pace of urbanization in developing countries is often cited as a key factor in the emergence and proliferation of slums and squatter settlements. It is not only generates economic growth, but also yields various environmental issues such as slum proliferation ${ }^{1)}$. As the result, at least 860 million people are now living in slums all over the world and the number keeps growing by six million each year from 2000 to $2010^{2}$.

As one of the most populated city in the world, Jakarta ${ }^{1}$ is experiencing rapid population growth. Its population reached around 9.7 million in 2012 and estimated will reach around 11.50 million in $2035^{3)}$. Consequently, the rapid population growth incites high population density which reached approximately 14,000 persons $/ \mathrm{km}^{2}$ in $2012^{3)}$. This immense urbanization provokes inadequate housing provisions to breed slum settlement as the reliable housing solution, especially for the underprivileged, who live in high-density neighborhood and deprived living quality ${ }^{4)}$. In the context of Jakarta, the underprivileged is whose monthly expenditure per capita is less than US\$ $35^{5}$.

According to BPS (2011) there are 44 Districts, 267 Sub-districts, 2,702 Community Associations $\left(\right.$ RW) ${ }^{2}$ and 30,203 Neighborhood Associations (RT) in Jakarta while 392 RWs are classified as slum settlements. Based on their research in 2011, the number of slum settlements is decreasing as many $5.54 \%$ since 2008-2011. This fact proves the existing slum improvement programs was able to reduce the number of slum settlements in slow acceleration which require more effective approach to achieve the expected outcome.

Slum settlement has several criteria such as: inadequate access to safe water; inadequate access to sanitation and other infrastructure; poor structural quality of housing; overcrowding; and, insecure residential status ${ }^{6}$. Due to limited physical standards, urban kampong in Indonesia shares some qualities with slum ${ }^{7}$.

Historically, kampong settlement has existed in Jakarta since Dutch colonial era, as soldier's settlement ${ }^{8)}$ and was governed based on mutual agreement among residents by each group ${ }^{9)}$ and free to determine its own standards ${ }^{10)}$. Since Independence era, Jakarta experiences massive in-migration ${ }^{11)}$ and new kampong settlements proliferate in unused space to provide escalating housing demand ${ }^{12}$, which makes some other kampongs are purely illegal ${ }^{13)}$. There were many kampong eviction programs for various extravagant construction projects such as arterial roads and public facilities to attract foreign direct investment but failed to reduce the slum ${ }^{14)}$.

The only reasonable alternative is to improve the existing settlements, because kampong dwellers constitute the major part of the urban population. The prominent governor, Ali Sadikin, introduced the first intervention to improve kampong, known as Kampong Improvement Program (KIP), in 1969 to improve the infrastructure in kampongs with the vision of integrating kampongs into a modern city through community empowerment ${ }^{14)}$. However KIP lost its sustainability because of the lack of secure tenure, as one of major factors ${ }^{14)}$.

The comprehensive KIP evaluation by World Bank ${ }^{15)}$ in Jakarta, Surabaya (East Java), and Denpasar (Bali) has proved that the program led directly to job creation or economic development in improved kampongs or elsewhere in the city remains insignificant. As with economic outcomes, a program that provides only a modest level of physical infrastructure upgrading may not yield dramatic improvements, because lack of secure tenure and social aspects that meet the related needs directly.

\subsection{The Challenges of Titling and Self-help Housing Improvement}

Slum dwellers are able to perform self-help housing and improvement, if they were provided with secure tenure, although they have insecure income ${ }^{16}$. Their secured tenure, following less fear of eviction, will encourages them to invest their resources to their housing needs. Thus, the land titling is 
encouraged to provide slum dwellers with the formal secured tenure based on individual freehold titles $^{17)}$.

It is worth keeping in mind that the concept of tenure security can be categorized into two types: Objective Tenure Security and Subjective Tenure Security ${ }^{18)}$. The former is provided through formal land regularization defined in land laws and/or the relevant governmental regulations. Meanwhile the latter is regarded as perceived tenure security through arrangements under customary law in the society ${ }^{19)}$, which can be provided without necessarily acquiring formal land registration as long as it is recognized in the society ${ }^{20)}$. In this categorization, the recent land titling encourages Objective Tenure Security.

Unfortunately, land titling did not have the intended results where the poor lose all the benefit it promised, such as: secure tenure and the possibility of living condition advancement ${ }^{21)}$. It encounters many tremendous obstacles such as time and cost due to administrative constraints ${ }^{22)}$, which makes it almost impossible to respond effectively under the rapid migration flow ${ }^{23)}$. Moreover it does not only increase the land market value but also increase the rent and tax prices, where the poor are likely to lose the right of their properties ${ }^{24)}$. It is Subjective Tenure Security, not Objective Tenure Security, that could make land easily available for the poor ${ }^{25}$.

In addition, the effect of land titling on self-help housing and improvement has been also dissapointing. Kampong dwellers, for example, who already obtained land titling had not improved their property because lack of money ${ }^{26}$. Housing improvement does not require Objective Tenure Security, but it is delivered particularly when slum dwellers become confident that eviction is thought to be unlikely ${ }^{27)}{ }^{28}{ }^{29}$. Taking the land availability and the slum dweller's motivation for housing improvement into consideration, the rise of Subjective Tenure Security is widely accepted as a precondition which is resonated by various researches ${ }^{24)} 30$ 31) 32) 33) that makes legal titles become obsolete.

\subsection{Land Titling in Indonesia}

In Indonesia, land titling has been implemented since the Dutch Colonial era. Under Dutch Colonial occupation, there are several land rights such as: right of ownership (eigendom), right of building (opstal) and right of exploitation (erfpacht). The colonial administration still acknowledged customary land right, which co-existed with the colonial land rights. These land rights were transformed in early independent era, through nationalization of Western properties occurred across the country. However the state was incapable to provide adequate land records and land administration system due to political turbulence ${ }^{34)}$. This condition opened wide opportunities for illegal occupation because of ambiguity of land ownership and rights. In order to prevent further land administration problems, the government produced Basic Agrarian Law in 1960 to regulate the land right $^{35)}$ and established National Land Agency to manages all grants, extensions, renewals of certified titles as well as running the land registration system. Under Basic Agrarian Law, the existing land rights are converted into 6 types of land right ${ }^{2}$ : Right of Ownership ${ }^{3}$, Right of Building ${ }^{4}$, Right of Strata Title Ownership on Multi-storey Building Units, Rights to Use, Right to Manage and Rights to Exploit. Yet, the conversion ${ }^{5}$ process encountered immense obstacles, such as weak legal framework and limited bureaucratic capacity ${ }^{34)}$. Thus, in order to accelerate number of land registration, Government Regulation 24/1997 allowed the land occupiers to register their lands if they meet several considerations, such as the land has been occupied 20 years or more, the occupation is strengthened by assertions from trustworthy persons, and the occupation does not infringe the customary law then accepted by local community. However, it has lead to discouraging the community, especially for kampong dwellers to register their lands, because the complicated and high-cost land registration procedures $^{34)}{ }^{35}$. The procedure requires the applicant to submit: 1) letter of undisputed land status; 2) letter of land parcel history; 3) letter of land occupation; 4) Identity and Family Card; 5) letter of land 
and building tax; and 6) letter of income tax. The document 1)-4) must be obtained from Sub-District Office while document 5)-6) from tax office. Announcement in local newspaper for 3 months is required to obtain document 1) and the applicant is responsible for the cost. After submitting the documents, the applicant must buy and fill the registration form in Municipality Land Agency, for verification. If the documents are valid, then the verification team from Municipality Land Agency comes to measure the land. The next step is Municipality Land Agency will submit the whole document to National Land Agency for obtaining the legalized certificate. Each step requires cost based on the land price and uncertain time, which burden the poor. This complexity can make only about 30 percent of Indonesia's non forest land is titled, compared to 90 percent in Thailand and 80 percent in Philippine ${ }^{36)}$.

\section{RESEARCH FRAMEWORK}

\subsection{Main Focus of the Previous Researches}

Most of the relevant researches on housing improvement in kampongs deal with the typology of kampongs $^{37) 6}$, problems of land regulations ${ }^{34)}{ }^{35)} 38$ ) and its practical solutions ${ }^{39)}$. Meanwhile, there are only small numbers of researches on land titling and its implication to kampong improvements. Among them, Winayanti and Lang ${ }^{40)}$ also Reerink and van Gelder ${ }^{41)}$ concluded that Subjective Tenure Security is not always based on property title, strengthened by community's recognition, becoming the main contributor to self-help incremental house improvements. These researches also asserted that the absence of Objective Tenure Security will not become impediment for kampong dwellers to improve their houses.

Nonetheless, it is true that many kampongs have been evicted though they have Subjective Tenure Security. This fact demonstrates that community's recognition, as the main source of Subjective Tenure Security, is not enough to avoid eviction. Therefore there must be additional factors that enable kampong settlements to survive, which has not been covered by previous researches. The factors such as location of kampong, various interventions to improve kampong not only by the government but also by the political parties and the other organizations/groups are noteworthy to be inquired.

\subsection{Research Aim and Methodolgy}

Considering the background and previous researches, this research, through a case of Kampong Cikini, Jakarta, aims (1) to understand the status of land ownership and their background by classifying the type of tenure security into Objective Tenure Security and Subjective Tenure Security, (2) to verify the implication of Sujective Tenure Security to house improvement by looking at the structural condition of houses and then (3) to discuss several factors that would strengthen Subjective Tenure Security to enable kampong residents to survive.

This research, keeping the sensitivity of land ownership, was carefully conducted. Firstly the several community engagement programs ${ }^{7}$ have been done since 2011 , the preliminary interviews with 5 local leaders were made in 2011-2013, and then in-depth semi-structured interviews were made to local leaders and 79 residents (head of a household ${ }^{8}$ or the one representing a household) in Kampong Cikini from April to July 2014 by employing snowball technique sampling ${ }^{9}$. The interview to the residents consists of reasons to reside, types of land ownership documents and methods to obtain them, obstacles of land registration, structural condition of houses, factors strengthening Subjective Tenure Secure, providers of Kampong Improvement Projects. In addition, this research was also enriched by information of legal ownership of National Raiway Company and the latest map in Kampong Cikini. 


\subsection{Case Study Area: Kampong Cikini}

In the local administration, the case study area belongs to RW1, Pegangsaan Sub-district, Menteng District in the municipality of Central Jakarta. In Menteng District, there are 906,601 residents within $48.13 \mathrm{~km}^{2}$. Among 5 Sub-districts in Menteng District Pegangsaan Sub-district is the highest density population district, where 27,934 people reside in $0.98 \mathrm{~km}^{2}$. Pegangsaan Sub-district consists of 8 $\mathrm{RWs}^{10}$ and RW1 has been well-known as Kampong Cikini (Figure-1).

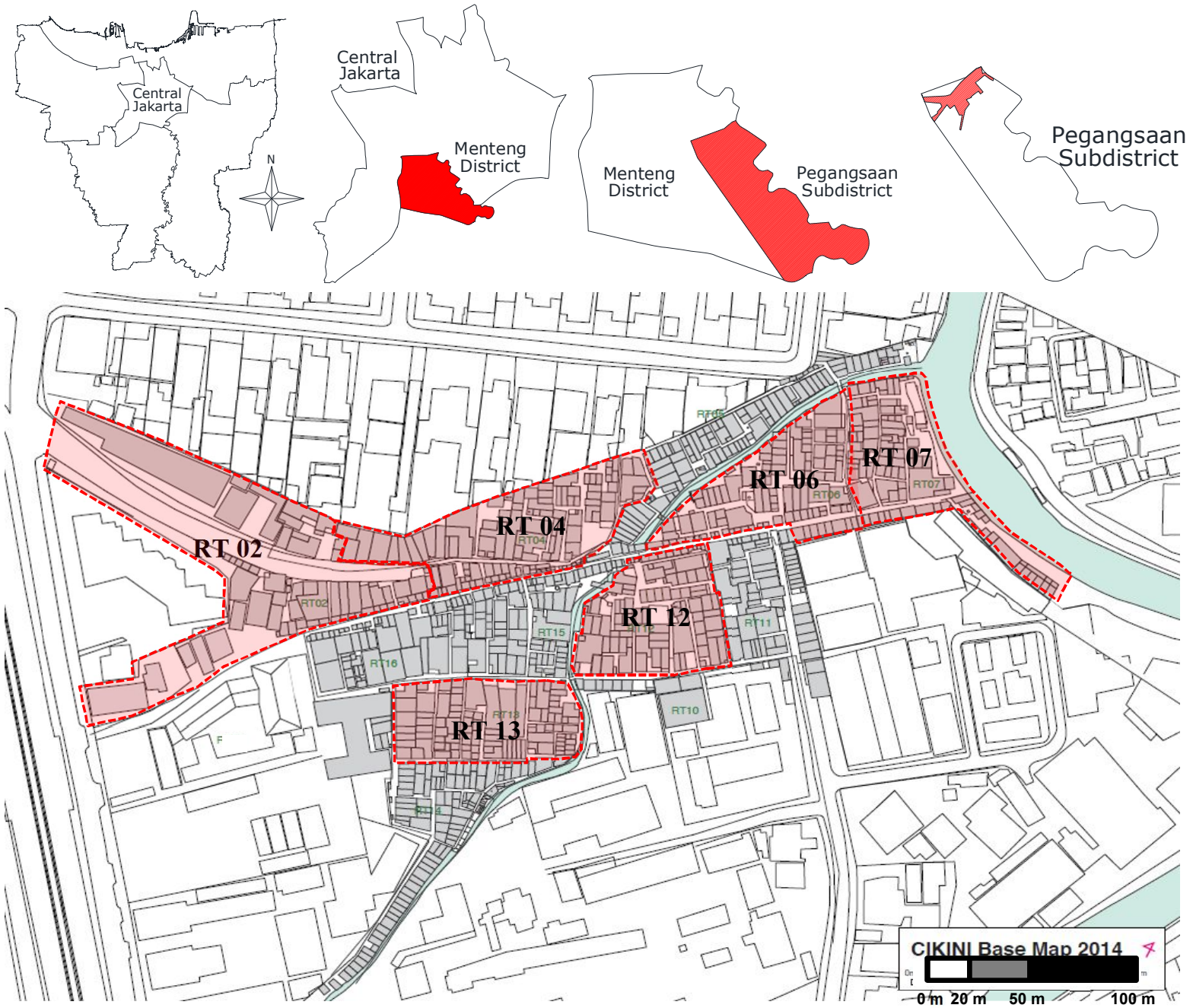

Figure-1 Location of Case Study Area: Kampong Cikini

Kampong Cikini once consisted of the housings for the workers of National Railways Company since the Dutch colonial era, and the population increased due to irrepressible in-migration rate after the railways overlayed project in 1960s. Most of the migrants were the traders in Cikini Market, which was built in 1962 to serve the basic needs of the Menteng elite society. This fast growing settlement was divided into 16 RTs in 1960s. In 1980s, when Pegangsaan sub district also emerged as bussiness district in 1980s, rapid modern development turned 5 RTs into commercial and public buildings, leaves only 11 RTs in the state of kampong. The 11 remaining RTs are: RT 2, 4, 5, 6, 7, 11, $12,13,14,15$ and 16, where approximately 942 households live within 4.01 hectares.

Until now, Kampong Cikini has been in the strategic location under rapid modern development. Its strategic location in Central Jakarta and surrounded by massive development, this kampong has been receiving many eviction threats over the years but remains exist despite having severe land tenure problems. Due to this reason, it is eligible to investigate the factors of Subjective Tenure Security in 
urban kampong ${ }^{39)}$ such as Kampong Cikini.

Regarding the respondents of interview, 5 residents from RT 2, 17 from RT 4, 11 from RT 6, 19 from RT 7, 14 from RT 12 and 13 from RT 13 that corresponds to $15 \%$ of total 556 households in these 6 RTs. Among these 79 respondents, 44 respondents are originated in Cikini Area, and 34 respondents have been residing for more than 40 years (Table-1). Most of respondents $(41.77 \%)$ affirmed that Kampong Cikini is the only place to live for them, which implied they did not have any alternative place to live outside this settlement. Their lands become the only asset that provide basic necessities for survival in Jakarta. There were only 7 of 79 respondents $(8.86 \%)$ choose to live in this settlement in order to be close to the family or relatives.

Table-1 Reasons to Reside of the Landowners

\begin{tabular}{|c|c|c|c|c|c|c|c|c|c|}
\hline \multirow{2}{*}{$\begin{array}{c}\text { Reason to } \\
\text { Reside in the } \\
\text { Area } \\
\text { Reside Time }\end{array}$} & \multirow{2}{*}{$\begin{array}{c}\text { Close to } \\
\text { Workplace }\end{array}$} & \multirow{2}{*}{$\begin{array}{l}\text { Close to } \\
\text { public } \\
\text { facilities }\end{array}$} & \multirow{2}{*}{$\begin{array}{c}\text { Close to } \\
\text { Family/ } \\
\text { Relatives }\end{array}$} & \multirow{2}{*}{$\begin{array}{c}\text { Fit in with } \\
\text { the } \\
\text { community }\end{array}$} & \multirow{2}{*}{ Settled } & \multirow{2}{*}{$\begin{array}{l}\text { The Only } \\
\text { Place to } \\
\text { Live }\end{array}$} & \multirow{2}{*}{$\begin{array}{l}\text { Decline to } \\
\text { Answer }\end{array}$} & \multicolumn{2}{|c|}{ Total } \\
\hline & & & & & & & & (n) & $(\%)$ \\
\hline $0-10$ yrs. & 2 & 2 & 1 & 0 & 2 & 2 & 0 & 9 & $11.39 \%$ \\
\hline $10-20 \mathrm{yrs}$. & 1 & 3 & 0 & 1 & 2 & 5 & 0 & 12 & $15.19 \%$ \\
\hline $20-30$ yrs. & 2 & 1 & 2 & 0 & 0 & 5 & 1 & 11 & $13.92 \%$ \\
\hline $30-40$ yrs. & 1 & 0 & 1 & 0 & 1 & 9 & 1 & 13 & $16.46 \%$ \\
\hline$>40 \mathrm{yrs}$ & 6 & 1 & 3 & 4 & 3 & 12 & 5 & 34 & $43.04 \%$ \\
\hline \multirow{2}{*}{ Total } & 12 & 7 & 7 & 5 & 8 & 33 & 7 & \multicolumn{2}{|c|}{79} \\
\hline & $15.18 \%$ & $8.86 \%$ & $8.86 \%$ & $6.33 \%$ & $10.12 \%$ & $41.77 \%$ & $8.86 \%$ & \multicolumn{2}{|c|}{$100.00 \%$} \\
\hline
\end{tabular}

These respondents are engaged in various occupations. However, some are civil servants $(1.85 \%)$ or private employee (5.56\%), the majority is self-employed (29.63\%) and daily labor (42.59\%) while19 respondents (17.59\%) are unemployed (3 declined to answer).

\section{STATUS OF LAND OWNERSHIPS AND THEIR BACKGROUNDS}

\subsection{Status of Land Ownership: Objective Tenure Security and Subjective Tenure Security}

Classifying Indonesia's land ownership into 2 types of Tenure Security, as Deininger ${ }^{18)}$ and the relevant researches do, Right of Ownership (A1 in Table-2) defined by Basic Agrarian Law can be classified as Objective Tenure Security (OTS), while other types of land ownership, like Inherited Right to Build (B1), Girik Letter ${ }^{11}$ (B2), Contract of Sale ${ }^{12}$ (B3), Receipt of Land Transaction ${ }^{13}$ (B4) and Inheritance Letter ${ }^{14}$ (B5), issued under the customary law or religious law, can be classified as Subjective Tenure Security (STS).

Table-2 Status of Land Ownership

\begin{tabular}{|c|c|c|c|c|c|c|c|}
\hline \multicolumn{2}{|c|}{ Type of Tenure Security } & \multicolumn{2}{|c|}{$\begin{array}{c}\text { Number of Respondents } \\
\text { (persons } / \%)\end{array}$} & \multicolumn{2}{|c|}{ Type of Land Ownership } & \multicolumn{2}{|c|}{$\begin{array}{c}\text { Number of Respondent } \\
\text { (persons } / \% \text { ) }\end{array}$} \\
\hline A) & $\begin{array}{c}\text { Objective Tenure } \\
\text { Security (OTS) }\end{array}$ & 2 & $2.53 \%$ & A1) & Right of Ownership & 2 & $2.53 \%$ \\
\hline \multirow{5}{*}{ B) } & \multirow{5}{*}{$\begin{array}{l}\text { Subjective Tenure } \\
\text { Security (STS) }\end{array}$} & \multirow{5}{*}{74} & \multirow{5}{*}{$93.67 \%$} & B1) & Inherited Right to Build & 8 & $10.13 \%$ \\
\hline & & & & B2) & Girik Letter & 11 & $13.92 \%$ \\
\hline & & & & B3) & Contract of Sale & 4 & $5.06 \%$ \\
\hline & & & & B4) & Receipt of Land Transaction & 9 & $11.39 \%$ \\
\hline & & & & B5) & Inheritance Letter & 42 & $53.16 \%$ \\
\hline C) & Decline to Answer & 3 & $3.80 \%$ & & & 3 & $3.80 \%$ \\
\hline \multicolumn{4}{|c|}{ Number of Respondents (persons) } & & & 79 & $100.00 \%$ \\
\hline
\end{tabular}




\section{Urban and Regional Planning Review \\ Vol. 3, 2016}

In the case study area, only 2 of 79 respondents $(2.53 \%)$ has registered their lands under Basic Agrarian Law to receive Right of Ownership, thus holding Objective Tenure Security. Most of respondents (93.67\%) hold Subjective Tenure Security, who claimed their landownership by possessing: Inherited Right to Build (B1) (10.13\%), Girik letter (B2) (13.92\%), Contract of Sale (B3) (5.60\%), Receipt of Land Transaction (B4) (11.39\%) and Inheritance Letter (B5) (53.16\%) (Table-2).

\subsubsection{Reasons to Obtain Right of Ownership under Basic Agrarian Law}

There are 2 out of 79 respondents who hold Objective Tenure Security in the case study area. They share the similar reasons to obtain Right of Ownership, for different reasons from the previous researches.

The one respondent is a resident of NA 2, who has lived for more than 40 years, and her family obtained the certificate in 1990 s by participating in conversion program by National Land Agency. As her family had already owned Right of Ownership under the Dutch Colonial Administration (Eigendom) before the program, she did not experienced significant obstacles although it took 5 years to complete the whole process. Yet, her participation's motive in the program was not to obtain the certificate to secure her tenure, which is expected to enable her to improve her house, as pointed out in the previous researches. The motivation, indeed, is to make the inheritance process easier. She admitted to reside in the family's land and all her relatives demand their inheritance rights to be distributed, which keeps mounting along with increase of land price, especially for the certified land. This reason indicates that the family has obtained Right of Ownership, under Basic Agrarian Law, in order to acquire profitable compensation by selling the land that would be divided to all family members under the customary law or the religion law.

The other respondent, residing in NA 4, also stated the similar reason to obtain Right of Ownership. In her case, just after purchasing the land almost 10 years ago, she registered the land, receiving the land certificate 2 years later. She explained by obtaining land certificate the land price is expected to increase 3-4 times higher in the case study area. Thus this higher land price gives her and family sense of security, as whenever they are forced to be evicted in the future to execute the spatial planning, they could move out and find the decent house in another location with higher amount of compensation she will receive.

The both cases of the respondents who hold Objective Tenure Security can tell that they has obtained Right of Ownership firstly for their economical reason, rather than for their secured tenure.

\subsubsection{Evidences of Land Ownership for Subjective Tenure Security}

As is shown in Table-2, the majority of the land owenership in the case study area is Subjective Tenure Security, counting up 74 out of 79 respondents. Among them, 42 respondents $(53.16 \%)$ claimed Inheritance Letter (B5) is their evidences of land ownership. This Inheritance Letter is issued according to the religious law or the customary law when their parents divided the land they possess into pieces for their children. Consequently, the children, as inheritors, perceive the letter as a kind of their land certificate that can replace the land certificate issued by National Land Agency, then they think they do not need to register their land.

The inheritance from the parents can be sometimes transferred through Inherited Right to Build (B1) or Girik Letter (B2). For the parents who once worked for Railway Company during the late Dutch Colonial and the early Independence Era, they were allowed to use the lands along the former railway line to built their houses and/or planted the crops as sign of appreciation for their services after the government decided to overlayed the railways in the mid-1950s. The owners of this Inherited Right to Build (B1) need to renew the license and register the land under Basic Agrarian Law and Government Regulation No. 24/1997, as the license has already has expired. Yet, they have not registered their 
land yet, and use the expired Inherited Right to Build as the evidence of the land ownership. Likewise, those respondents who claimed Girik Letter (B2) has expired letter. Although Inherited Right to Build (B1) and Girik Letter (B2) were legally issued by the government, they cannot be regarded as formal landowner because they fail to meet the requirements, despite they possess the acknowledged documents.

On the other hand, Contract of Sale (B3) and Receipt of Land Transaction (B4), which are regarded as evidence of transaction among the community members, are also claimed as the legitimate evidence of land ownership. Therefore, the owners of those documents do not think they need to register the land to National Land Agency. Furthermore, the methods to obtaining these evidences illustrates more complex land ownership in the case study area (Table-3).

Naturally, many of the landowners with Inherited Right to Build (B1), Girik Letter (B2) and Inheritance Letter (B5) have obtained the documents through inheritance. All respondents with Contract of Sale (B3) and 4 out of 9 landowners with Receipt of Land Transaction (B4) have done it by purchasing the land. Yet, there is 1 respondent who has purchased Girik Letter (B2), using it as evidence of land ownership through land transaction. In this case, Girik Letter (B2) acts as replacement of Contract of Sale (B3) and Receipt of Land Transaction (B4). There are 10 respondents who claimed their landownership by Inherited Right to Build (B1) and Receipt of Land Transaction (B4) actually owned by their relatives. In these cases, they are allowed to occupy the land of their relatives living elsewhere and promised to be the landwoners when their relatives passed away. In other words, the Inherited Right to Build (B1) or Receipt of Land Transaction (B4) will be inherited to them in the future.

Table-3 Evidences of Landownership for Subjective Tenure Security and Obtainment Methods

\begin{tabular}{lccccc}
\hline \multirow{2}{*}{ Alternative Evidence of Landownership } & \multicolumn{2}{c}{ Landownership Obtainment Methods } & \multicolumn{2}{c}{ Number of Respondents } \\
\cline { 2 - 6 } & Occupy Relative's Land & Inheritance & Purchase & (persons) & (\%) \\
\hline B1) Inherited Right to Build & 5 & 3 & 0 & 8 & $10.81 \%$ \\
B2) Girik Letter & 0 & 10 & 1 & 11 & $14.86 \%$ \\
B3) Contract of Sale & 0 & 0 & 4 & 4 & $5.41 \%$ \\
B4) Receipt of Land Transaction & 5 & 0 & 4 & 9 & $12.16 \%$ \\
B5) Inheritance Letter & 0 & 42 & 0 & 42 & $56.76 \%$ \\
\hline Total $(\boldsymbol{n})$ & $\mathbf{1 0}$ & $\mathbf{5 5}$ & $\mathbf{9}$ & $\mathbf{7 4}$ & $\mathbf{1 0 0 . 0 0 \%}$ \\
\hline
\end{tabular}

Looking into the evidences of land ownership for Subjective Tenure Security, it is found that they have their own reason (and they think good reason) to claim their land ownership through different documents such as Inherited Right to Build (B1), Girik Letter (B2), Contract of Sale (B3), Receipt of Sale (B4) and Inheritance Letter (B5) by being inherited from their parents or purchasing it. In addition, some will inherit the land by occupying their relative's land. These different evidences of land ownership through these different processes of obtaining it makes Subjective Tenure Security more complicated, though it is the majority in the case study area.

\subsection{Obstacles of Land Registration}

Despite the fact that most of the respondents (73.41\%) have lived there for more than 20 years (Table1) and the Government Regulation 24/1997 allowing the land occupiers to register their lands if they occupy the land for more than 20 years, the majority of the land ownership is Subjective Tenure Security, not Objective Tenure Security. In other words, they do not register their lands, though it is expected to do because of several obstacles (Table-4).

The major obstacles for land registration is their inadequate knowledge of land administration. In fact, 
the procedure of formal land registration is too complicated due to the number of the relevant government regulations they are required to comprehensively understand. However, even if they (and even partly) understand it, the expensive registration cost becomes inevitable obstacle (20 of 68 respondents). The registration cost will be decided based on the official land price, according to Government Regulation 13/2010, which would lead to the increase of the cost under increasing land price. Indeed, the official land price of this kampong is approximately US $\$ 250-500 / \mathrm{sqm}^{15}$, beyond most of their financial capacity, even if their lands are small.

Table-4 Obstacles of Land Registration

\begin{tabular}{|c|c|c|c|c|c|c|c|}
\hline \multirow{2}{*}{ The Obstacle of Land Registration } & \multicolumn{7}{|c|}{ Reside Time in Cikini Area } \\
\hline & 0-10 yrs. & 10-20 yrs. & 20-30 yrs. & 30-40 yrs. & $>40$ yrs. & & Total \\
\hline Inadequate Knowledge of Land Administration & 11 & 4 & 2 & 5 & 2 & 24 & $35.29 \%$ \\
\hline Expensive & 10 & 3 & 2 & 3 & 2 & 20 & $29.41 \%$ \\
\hline Time Consuming & 4 & 0 & 0 & 2 & 3 & 9 & $13.24 \%$ \\
\hline Avoid Land Tax & 5 & 0 & 1 & 1 & 0 & 7 & $10.29 \%$ \\
\hline Mismatch with Spatial Planning & 2 & 0 & 1 & 0 & 3 & 6 & $8.82 \%$ \\
\hline Belongs to Family & 1 & 0 & 1 & 0 & 0 & 2 & $2.94 \%$ \\
\hline Total (n) & 33 & 7 & 7 & 11 & 10 & & $68 *)$ \\
\hline Total (\%) & $48.53 \%$ & $10.29 \%$ & $10.29 \%$ & $16.18 \%$ & $14.71 \%$ & & $100.00 \%$ \\
\hline
\end{tabular}

In addition, there are 7 of 68 respondents $(10.29 \%)$ who realized the obligation to pay the land tax as the inevitable consequence of land registration. After spending much for land registration, paying annual land tax would not be preferable for them. Another obstacle worth highlighting comes from the land ownership. 2 respondents (2.94\%) answered because their lands belong to their family, which compel them to deliberate with other family members to register the lands. Land registration has been discouraged in this case study area mainly due to their inadequate knowledge and the expensive cost both for registration and following tax. In this situation, land registration is thought to be time consuming, which would lead to further discouraging the registration.

\section{RELATIONSHIP BETWEEN LAND OWNERSHIP AND HOUSING CONDITION}

Theoretically, those who rely on Subjective Tenure Security, will fell fear of eviction and reluctant to improve their houses. However, the data regarding the relationship between land ownership and housing condition in the case study area (Table-5) shows interesting tendency that is not expected in the previous researches. Although most of the respondents hold Subjective Tenure Security, 60 out of all the 79 respondents $(75.95 \%)$ build their houses in permanent structure. Indeed, 56 of 74 respondents (75.68\%) under Subjective Tenure Security (from B1 to B5) have permanent houses. Rather, there is 1 respondents under Objective Tenure Security (A1) has a semi-permanent house. Therefore type of tenure security does not affect their housing condition very much in the case study area.

Furthermore land status in Kampong Cikini, according to National Land Agency, was unregistered, which also challenge National Railway Company's claim as landowner. National Railway Company, as the pressumed landowner, could not claim their ownership as they had insufficient data of land delienation. 
Table-5 Land Ownership and Structural Condition of Houses

\begin{tabular}{|c|c|c|c|c|c|c|}
\hline \multirow[b]{2}{*}{ Type of Land Ownership } & \multicolumn{2}{|c|}{ Permanent $^{1)}$} & \multicolumn{2}{|c|}{ Semi-Permanent $^{2)}$} & \multicolumn{2}{|c|}{ Total } \\
\hline & (n) & $(\%)$ & (n) & $(\%)$ & (n) & $(\%)$ \\
\hline A1) Right of Ownership & 1 & $1.67 \%$ & 1 & $5.26 \%$ & 2 & $2.53 \%$ \\
\hline B1) Inherited Right to Build & 4 & $6.67 \%$ & 4 & $21.05 \%$ & 8 & $10.13 \%$ \\
\hline B2) Girik Letter & 10 & $16.67 \%$ & 1 & $5.26 \%$ & 11 & $13.92 \%$ \\
\hline B3) Contract of Sale & 3 & $5.00 \%$ & 1 & $5.26 \%$ & 4 & $5.06 \%$ \\
\hline B4) Receipt of Land Transaction & 7 & $11.67 \%$ & 2 & $10.53 \%$ & 9 & $11.39 \%$ \\
\hline B5) Inheritance Letter & 32 & $53.33 \%$ & 10 & $52.63 \%$ & 42 & $53.16 \%$ \\
\hline C) Decline to Answer & 3 & $5.00 \%$ & 0 & $0.00 \%$ & 3 & $3.80 \%$ \\
\hline Total & 60 & $75.95 \%$ & 19 & $24.05 \%$ & 79 & $100.00 \%$ \\
\hline
\end{tabular}

1) The definition of permanent structure house regards to the degree of movability. The permanent structure is defined as non-movable structure because it is intended to stay permanent in a location and the materials cannot be detached after the construction has finished.

2) The definition of semi-permanent structure refers to the ability some parts of structure to be attached, transported and construct elsewhere.

Table-6 Factors Strengthening Subjective Tenure Security

\begin{tabular}{|c|c|c|c|c|c|}
\hline $\begin{array}{l}\text { Reasons } \\
\end{array}$ & \multirow{2}{*}{$\begin{array}{c}\text { Support from Political Party \& } \\
\text { Mass Organizations }\end{array}$} & \multirow{2}{*}{$\begin{array}{c}\text { Intervention to Improve } \\
\text { Kampong }\end{array}$} & \multirow{2}{*}{ Expensive Cost of Land } & \multicolumn{2}{|c|}{ Total } \\
\hline Reside Time & & & & (n) & $(\%)$ \\
\hline $0-10 \mathrm{yrs}$ & 0 & 3 & 4 & 7 & $12.28 \%$ \\
\hline $10-20$ yrs. & 1 & 6 & 1 & 8 & $14.04 \%$ \\
\hline $20-30$ yrs. & 4 & 1 & 2 & 7 & $12.28 \%$ \\
\hline $30-40$ yrs. & 1 & 2 & 7 & 10 & $17.54 \%$ \\
\hline$>40 \mathrm{yrs}$ & 3 & 6 & 16 & 25 & $43.86 \%$ \\
\hline \multirow{2}{*}{ Total (n/\%) } & 9 & 18 & 30 & \multirow{2}{*}{\multicolumn{2}{|c|}{$\frac{57}{100.00 \%}$}} \\
\hline & $15.79 \%$ & $31.58 \%$ & $52.63 \%$ & & \\
\hline
\end{tabular}

Table-7 Providers of Intervention to Improve Kampong in Cikini

\begin{tabular}{|c|c|c|c|c|c|c|}
\hline The Provider & (numbers) & $(\%)$ & Name of Intervention & (numbers) & Object of Improvement & (numbers) \\
\hline Anonymous $^{1)}$ & 5 & $6.02 \%$ & Anonymous ${ }^{1)}$ & 5 & Communal Bathroom/ Drainage & 5 \\
\hline \multirow{8}{*}{ Government } & \multirow{8}{*}{68} & \multirow{8}{*}{$81.93 \%$} & \multirow{2}{*}{ Anonymous ${ }^{1)}$} & \multirow{2}{*}{17} & Communal Bathroom/ Drainage & 7 \\
\hline & & & & & Neighborhood's Street Improvement & 10 \\
\hline & & & MHT/ KIP & 3 & Neighborhood's Street Improvement & 3 \\
\hline & & & \multirow{3}{*}{ PNPM Mandiri } & \multirow{3}{*}{18} & Communal Bathroom/ Drainage & 8 \\
\hline & & & & & Neighborhood's Street Improvement & 8 \\
\hline & & & & & House Improvement & 2 \\
\hline & & & \multirow{2}{*}{ PPMK } & \multirow{2}{*}{30} & Communal Bathroom/ Drainage & 5 \\
\hline & & & & & Neighborhood's Street Improvement & 25 \\
\hline \multirow{3}{*}{$\begin{array}{l}\text { Political Party and } \\
\text { Mass Organizations }\end{array}$} & \multirow{3}{*}{7} & \multirow{3}{*}{$8.43 \%$} & \multirow{3}{*}{ Anonymous ${ }^{1)}$} & \multirow{3}{*}{7} & Communal Bathroom/ Drainage & 1 \\
\hline & & & & & Neighborhood's Street Improvement & 3 \\
\hline & & & & & House Improvement & 3 \\
\hline Private Company & 1 & $1.20 \%$ & $\begin{array}{c}\text { Corporate Social } \\
\text { Responsibility } \\
\text { Program (CSR) }\end{array}$ & 1 & Neighborhood's Street Improvement & 1 \\
\hline University & 2 & $2.41 \%$ & Anonymous ${ }^{1)}$ & 2 & Communal Bathroom/ Drainage & 2 \\
\hline Total (n) & 83 & & & & & \\
\hline
\end{tabular}

1) Due to many fragmented additional kampong improvement projects nowadays, the kampong dwellers have difficulties to identify the provider and the name of programs. Many of them were not recorded appropriately in any level of government bodies. Therefore we use the term anonymous, referring to unknown providers and name of projects. 
This kind of support also appears in intervention to improve Kampong, as shown in Table-6. After KIP was terminated in 1980s, intervention to improve Kampong delivers by various parties, such as: government, political party, private company and university. These projects were delivered with lack of integration by various donors according to personal interests, unlike the original KIP.

The expensive cost of land, interventions to improve kampong and backup by political parties also strengthen their Subjective Tenure Security. This rapid land price escalation also prevents the execution of future spatial planning ${ }^{15}$. According to Head of Pegangsaan Sub District, the government and private company cannot afford the overall land clearance, which contributes to increase Subjective Tenure Security.

There are 68 of 83 interventions to improve kampong since the 1980s have been provided by government, through many top-down programs from central government such as Program Nasional Pemberdayaan Masyarakat (National Program for Community Empowerment) from national government and Program Pemberdayaan Masyarakat Kelurahan (Village Program for Community Empowerment) from city government (Table-7). These programs were formulated and delivered by central government to reduce the number of slum settlement and growing rate of poverty. Although reluctance to acknowledge the existence of slum dwellers, the city government must complied with the mandatory central government's top-down programs and translated them into various projects. This condition was comprehended by slum dwellers as legitimation of their existence from government which induces the Subjective Tenure Security.

Support from political parties, as well as many mass organizations, contributes as strengthening factor of Subjective Tenure Security. Mass organizations are looking for members to support them and interventions to improve kampong are regarded as an efficient persuasion to generate members from kampong settlement. While political parties compete to generate votes from kampong dwellers by improving the public infrastructures such as: communal bathroom, drainage, neighborhood's street and house, which were delivered every in pre-election time. According to Head of RW 1, some political members came to the neighborhood and offered some interventions to improve kampong, in order to advance votes from kampong dwellers. The projects encompassed communal bathrooms, neighborhood's street and even house improvement improvements, as shown in Table-7. Although slum dwellers recognized the projects as a political bribe in exchange for their votes, they exploit these mutual relationships to generate support from mass organizations and political parties to challenge the government's eviction plan. According to Head of RW 1 \& several Head of RTs, this support encourages their Subjective Tenure Security and has proven as survival means from enduring eviction plans.

\section{CONCLUSION}

Under Basic Agrarian Law and the relevant regulations and programs, the government has been expected to increase the number of land registration. In this sense, the residents in Cikini Area have advantageous conditions such as the strategic location in the center of the capital and access to city infrastructures and high land price. Moreover, most of them have resided more than 20 years making them eligible to register their land formally to National Land Agency.

However, as supported by the previous researches, it is less than $3 \%$ out of the respondents have Objective Tenure Security in Cikini, who has registered their lands to obtain Right of Ownership, to earn higher profit from selling their lands. On the other hand, the low number of land registration is inevitable result from the existence of various (and sometimes expired) documents, such as Inherited Right to Build, Girik Letter, Contract of Sale, Receipt of Land Transaction, Inheritance Letter, which are also considered as evidence of land ownership by them, which theoretically are classified as Subjective Tenure Security. 


\section{Urban and Regional Planning Review \\ Vol. 3, 2016}

There are several obstacles can be pointed out that contribute to discouraging land registration such as:

- One major obstacle is inadequate knowledge about land administration, because Indonesia's land registration is very complicated and confuse the residents with all its regulations and procedures;

- The financial incapacitated also discourages the kampong dwellers to register their lands because the cost of land registration and the annual land tax are very expensive, especially because of the location in the center of the capital.

Despite the absence of Objective Tenure Security, the residents still perform self-help housing improvements by building permanent houses. In fact, Objective Tenure Security also does not necessarily guarantee the landowners to perform such improvement. Furthermore, Subjective Tenure Security is strengthened by the following additional factors, as stated in the hypothesis, such as:

- The strategic location propels the land price which would requires the government to provide huge amount of compensation for eviction;

- Various interventions to improve kampong are regarded as recognition of their existence;

- Political parties and the other organizations/groups support which enable them to survive from fear of eviction over the years.

Because of the obstacles and additional factors, the land registration in Indonesia is lower than the neighboring countries, where approximately $30 \%$ non-forest land. The finding shows the number of land title in urban kampong is even lower.

The acknowledgement and registration of the existing documents of land ownership is important to provide tenure security of kampong dwellers. This step benefits the city government officials to collect legitimate data of population and land ownership condition to formulate better regulation. Nonetheless formal land ownership is not necessary to prevent land transaction and preserve their existence in the city. Formal land ownership will diminish their existence because their lack of financial capacity to cope with the increasing of land tax price as a result of the increasing of land price in the city center. The existing land ownership enables self-help house provision and sustenance of livelihoods. Therefore special land ownership system for slum dwellers is required, which is not equal to citizens in the high and middle income groups, who can afford to compensate land tax price. The acknowledgement of sufficient data of population and types of existing land ownership from registration will enable city government to comprehend the real condition of the specific kampong to formulate the precise interventions to improve kampong in the future. It will resolve the problem of fragmented program of interventions to improve kampong.

The acknowledgement also enable provide tenure security for the kampong dwellers to live in the strategic location. Their existence must be elaborated in the review of the established city spatial planning. The approval of interventions and budgeting to improve kampong based on the matched spatial planning will become the suitable role of political parties rather than deliver the interventions to collect votes. Therefore the mismatch location of kampong area in the spatial planning, fragmented interventions to improve kampong and the role of political parties, as identified in the findings, can be eliminated. The accommodation of these suggestions will establish kampong as integrated entity of the city through tenure security attainment and living condition improvement, as the main objective and benefit of the improvement programs.

These findings do not only complement the existing theory of tenure security but also demonstrate how Subjective Tenure Security, with its strengthened factors, encourages self-help housing improvements in slum settlement. Yet, this research focuses only one kampong in one location due to the limited resource. More case studies with expanding number of kampongs and respondents are suggested to reduce the bias and reaching comprehensive understanding of this essential issue. It will 
be efficacious to formulate the effective land titling policy to provide tenure security for kampong dwellers that compatible with their social, cultural and economic context, especially in Jakarta.

\section{ACKNOWLEDGEMENTS}

The authors would like to express their sincere gratitude to Japan Society for Promoting Science (JSPS) and Directorate of Research and Community Engagement Universitas Indonesia for funding the research. The enormous contributions from Mohammad Fazrin Rahman, Libratono, Fitri Aisyah, Meidesta Pitria and Yuki Yoshikata during data collecting stage are fully acknowledged.

\section{NOTES}

1 Jakarta is divided into five municipalities and 1 regency which are Central, East, West, North and South Jakarta also Thousand Islands Regency. Each municipality or regency consists of several districts and each districts comprise of several sub districts. In order to facilitate public service, each sub districts are supported by several RW (Rukun Warga or Community Association) while each RW has several RT (Rukun Tetangga or Neighborhood Association) ${ }^{3) 5) 13)}$.

$2 \mathrm{RO}$ and $\mathrm{RB}$ are relevant to this study while the third is applied for multi-stories apartment's tenant and the last four are relevant for cultural, commercial and agriculture activities ${ }^{19)}{ }^{26)}{ }^{34}$.

3 Right of Ownership (RO) grants absolute ownership of a plot of land which is hereditary and may be held only by individuals ${ }^{19)}{ }^{26)}{ }^{34)}$.

4 Rights of Building (RTB) gives the right to construct and own buildings on a plot of land which is granted by the National Land Agency for an initial period of up to 30 years and is extendable for a subsequent 20 -years period ${ }^{19)}{ }^{26)}{ }^{34)}$.

5 The conversion of eigendom was compulsory. If the landholder was Indonesian, the eigendom was converted to a right of ownership (RO). It was converted to Right to Build (RB) for a maximum of twenty years to landholders who held dual nationality or who failed to report their entitlement within a one year period. While the Western right of building (opstal) and the Western right of exploitation (erfpacht) were converted into a Right to Build (RB) or a right of exploitation (RE) depending on the status of the land. Land in residential areas was converted into land with a Right to Build (RB), but it was converted to right of exploitation (RE) if used for agricultural activities. All those land rights were expected to be converted within a year after the enactment of BAL, otherwise it would revert to state ownership ${ }^{19)}{ }^{26)}{ }^{34)}$.

6 According to their longitudinal researches in Surabaya (Indonesia), Funo et. al ${ }^{39)}$ emphasized each kampung has its own characteristics, which varies with its location (distance from the city center), constitution of income groups, migratory backgrounds of inhabitants or mobility of population, its history its spatial pattern and so on. He classified kampong in Indonesia into 3 categories, urban kampung, fringe kampung, and rural kampung, which is made according to their location.

7 The concept of household refers to different groups of people living in the same house, but having two or more separate family incomes were counted as separate households even if sharing the same house. Moreover, members of the same family living in two or more houses occupying the same plot were considered separate households ${ }^{22)}$.

8 We performed the community engagement programs with participatory design method since 20112013, which funded by Directorate Research and Community Engagement Universitas Indonesia. Since 2011, we collaborate with the kampong dwellers in Cikini Area to rehabilitated and provided public facility to improve their living condition.

9 Land ownership status is very sensitive issue especially in urban kampong because the settlement has been surrounded by eviction threats for almost 40 years. Due to reluctance of respondents snowball sampling method as employed to reach the hard-to-reach and/or hidden populations who possess valuable information through a chain of nominations and re-nominations ${ }^{42)}$. This sampling 
technique requires contact and interviewed a 'first order' zone of the network that will then nominate those that become the 'second order' zone and so on in a chain method that will reveal a complete network component. Local leaders were regarded as the 'first order zone' and they nominated the community members, as 'second order zone', who are considered as reliable respondents.

10 The concept of RW (Rukun Warga or Community Association/ Tonarigumi) and RT (Rukun Tetangga or Neighborhood Association/ Azzazyokai) are the reorganization of settlement within the village through the introduction of the Tonarigumi system during Japan occupation in 19421945. These concepts are repeated in the development of a resident organization, during the Soekarno period and the new order regime of Suharto ${ }^{12)}$.

11 Girik letter was permit to control and use the designated land in Dutch Colonial period that legitimate to prove someone's land ownership. This letter is acknowledged by the National Land Agency but does not entitle them the rightful ownership of the property ${ }^{19) 26) 34)}$.

12 In the process of purchasing land, there were two or more persons witnessed the process of transaction by both parties. The holders perceived the transaction process as the transfer of land ownership from the previous to the new owner. The community leaders also witnessed the process and signed in the contract document as token of community's recognition. In this case, community's recognition as source of STS is not only practiced informally but also documented in the contract of sale.

13 It is different with the Contract of Sale because it did not witnessed by two or more other persons. Nonetheless the new owner of the land is still eligible to earn community's recognition by showing the receipt to the neighbors and leaders whenever it is needed.

14 For kampong dwellers, it is enough to represent their landownership and replace the formal certificate. They argued that the religious law is sourced from God verses while statutory law is created by man. This argument was based on interview with respondents, which also corresponds to Harsono ${ }^{19)}$.

15 This information of official Map of Land Status and Land Value can be accessed from: http://peta.bpn.go.id/\# (accessed on: November $\left.5^{\text {th }}, 2014\right)$.

\section{REFERENCES}

1) UN-Habitat., 2010. Citywide Action Plan for Upgrading Unplanned and Unserviced Settlements in Dar es Salaam. Nairobi: UN-HABITAT.

2) UN-Habitat., 2012. Sustainable Urbanization in Asia: A Source Book for Local Government. Nairobi: United Nations Human Settlements Programme.

3) Badan Pusat Statistik., 2013. Indonesia Population Projection 2010-2035. BPS: Jakarta.

4) Hao, P., Sliuzas, R., Geertman, S. 2011. The development and redevelopment of urban villages in Shenzhen. Habitat International, 35(2): 214-224.

5) Badan Pusat Statistik., 2015. Jakarta Dalam Angka 2015. BPS: Jakarta (Indonesian).

6) UN-Habitat., 2003. The Challenge of Slums. London: Earthscan Publications Ltd.

7) Silas, J., 1992. Government - community partnerships in Kampung Improvement Programmes in Surabaya, Environment and Urbanization, 4(2).

8) Blussé, L., 2008. Visible Cities: Canton, Nagasaki and Batavia and the coming of the Americans. Cambridge: Harvard University Press.

9) Nas, P.J.M., and K. Grijns. 2000. Jakarta Batavia: Socio-cultural essays. Leiden: KITLV Press.

10) Harun, I. B., 1993. Kampong Tua di Jakarta. Jakarta: Dinas Museum dan Sejarah DKI Jakarta (Indonesian).

11) Jellinek, L., 1991. The wheel of fortune: The history of a poor community in Jakarta. Honolulu: University of Hawaii Press. 
12) Somantri, G.R., 2007. Migration within cities: A study socio-economic processes, intra-city migration, and grass-roots politics in Jakarta. Jakarta: Lembaga Penerbit Fakultas Ekonomi Universitas Indonesia.

13) Tunas, D., 2008. The Spatial Economy in the Urban Informal Settlement. Delft: IFoU.

14) Silver, C., 2008. Planning the megacity: Jakarta in the twentieth century. London: Routledge.

15) World Bank. 1995. Indonesia Impact Evaluation Report Enhancing the Quality of Life in Urban Indonesia: The Legacy of Kampung Improvement Program, Jakarta: World Bank.

16) Turner, J. F. C., 1968. Housing priorities, settlement patterns, and urban development in modernizing countries. American Institute of Planners Journal, 10(10): 354-363.

17) de Soto, H., 2000. The Mystery of Capital: Why capitalism triumphs in the west and fails everywhere else. London: Bantam Press.

18) Deininger, K., 2003. Land Policies for Growth and Poverty Reduction. Washington D.C: World Bank.

19) Harsono, B., 2008. The Indonesian Agrarian Law: Historical Formation of the Land Act, Content and Implementation. Jakarta: Djambatan.

20) Abdulai, R.T., 2006. Is Land Title Registration the Answer to Insecure and Uncertain Property Rights in Sub-saharan Africa? RICS Research Paper Series, 6(6): 1-27.

21) Durand-Lasserve, A., 2003. Land Tenure, Property System Reforms and Emerging Urban Land Markets in Sub-Saharan Africa, Comparative Policy Perspectives on Urban Land Market Reform in Eastern Europe, Southern Africa and Latin America, Lincoln Institute of Land Policy.

22) Payne, G., A. Durand-Lasserve, and C. Rakodi., 2007. Social and Economic Impacts of Land Titling Programmes in Urban and Peri-urban Areas: A Review of the Literature. In World Bank Urban Research Symposium. Washington DC, USA, 14-16 May 2007.

23) Durand-Lasserve A., 2006. Informal Settlements and the Millennium Development Goals: Global Policy Debates on Property Ownership and Security of Tenure. Global Urban Development, 2(1):1-15.

24) Payne, G., 2001. Urban Land Tenure Policy Options: Titles or Rights? Habitat International, 25: 415-429.

25) Durand-Lasserve, A., and G. Payne., 2006. Evaluating Impacts of Urban Land Titling. Results and Implications: Preliminary Findings. London: CNRS.

26) Hardjono, J., 1999. A social assessment of the land certificate program. The Indonesian Land Administration Project. Jakarta: Unpublished report prepared for the World Bank.

27) Varley, A., 1987. The relationship between tenure legalization and housing improvements: Evidence from Mexico City. Development and Change, 18(3): 463-481.

28) de Souza, F. A. M., 2001. Perceived security of land tenure in Recife, Brazil, Habitat International, 25: 175-190.

29) van Gelder, J., 2007. Feeling and thinking: Quantifying the relationship between perceived tenure security and housing improvement in an informal neighbourhood in Buenos Aires. Habitat International, 31(2): 219-231.

30) Calderon, J., 2004. The formalization of property in Peru 2001-2002: The case of Lima. Habitat International, 28(2): 289-300.

31) Gilbert, A., 2002. On The Mystery of Capital and the Myths of Hernando De Soto: What Difference Does a Legal Title Make? International Development Planning Review, 24(1): 1-19.

32) Porio, E., and C. Crisol., 2004. Property rights, security of tenure and the urban poor in Metro Manila. Habitat International, 28(2): 203-219.

33) Savant-Mohit, R., 2004. Security of tenure and the way forward: The case of Samakee Pattana, Bangkok. Habitat International, 28(2): 301-316.

34) Daryono., 2010. Transformation of Land Rights in Indonesia: A Mixed Private and Public Law 
Model. Pacific Rim Law \& Policy Journal, 19(3): 417-457.

35) Heryani, E., and C. Grant., 2004. Land Administration in Indonesia, 3rd FIG Regional Conference, Jakarta, Indonesia, October 3-7, 2004.

36) Shu, J., 2010. Symmetric Development of Informal Settlements and Gated Comunities: The Case of Jakarta (Indonesia), Working Paper Series No, 135, Singapore: Asia Research Institute.

37) Arizona, Y., 2010. Antara teks dan konteks: Dinamika pengakuan hukum terhadap hak masyarakat adat atas sumber daya alam di Indonesia, Jakarta: Perkumpulan HuMa. (Indonesian).

38) Yosita, L., and U. Surahman., 2007. Strategy of Urban Kampong Development: Analysis of Prospect and Modelling Land Sharing as an Alternative Toward Conventional Approach, Jakarta: Unpulblished Report of University Research Colaboration Grant Program.

39) Funo, S., Yamamoto, N., and J. Silas. 2002. Typology of Kampung Houses and Their Transformation Process: A Study on Urban Tissues of an Indonesian City. Journal of Asian Architecture and Building Engineering, 1(2): 193-200.

40) Winayanti, L., and H. C. Lang., 2002. Provision of urban services in an informal settlement: a case study of Kampung Penas Tanggul, Jakarta. Habitat International, 28: 41-65.

41) Reerink, G., and J-L van Gelder., 2010. Land titling, perceived tenure security, and housing consolidation in the kampongs of Bandung, Indonesia. Habitat International, 34: 78-85.

42) Thompson, S. K. 2002. Sampling. London: Wiley. 